\title{
Pętla śmierci jako komponent
}

Olli Tapio Leino 
Pętla śmierci jako komponent

Olli Tapio Leino

TEKSTY DRUGIE 2017, NR 3, S. 116-145

DOI: $10.18318 /$ td.2017.3.7

\section{Wprowadzenie}

W niniejszym eseju postaram się naświetlić kwestie interpretacji gier jednoosobowych podczas rozgrywki (single-player computer games as played), a konkretniej: będę teoretyzował na temat możliwości interpretacji Fallout: New Vegas (2010). I chociaż sam esej dotyczy New Vegas i interpretacji, nie jestem zainteresowany graczami i ich interpretacjami, ale samym New Vegas jako dziełem otwierającym się na interpretację graczy takich jak ja. Tym samym nie będę proponował nowych metod interpretacyjnych dla gier komputerowych ani też nie będę mówił o tym, co New Vegas oznacza. Zamiast tego proponuję spojrzenie na gry komputerowe w duchu poniekąd husserlowskim - z perspektywy poprzedzającej interpretację - i stawiam następujące pytanie: jak "gry" takie jak New Vegas mogą w ogóle być interpretowane?

Kwestie związane z interpretacją zostały zasygnalizowane w centralnym punkcie debaty „ludologia kontra narratologia"; przeważała wtedy jednak niepewność,

\section{Olli Tapio Leino -}

zatrudniony jako

assistant professor na

Miejskim Uniwersy-

tecie w Hongkongu,

autor pracy doktor-

skiej poświęconej fe-

nomenologicznemu

ujęciu doświadczenia

emocjonalnego

graczy. Zajmuje się

badaniem gier wideo

oraz sztuki cyfrowej,

głównie z perspek-

tywy fenomenologii

egzystencjalnej.

Autor licznych publi-

kacji z zakresu filozofii

gier, włączających

w namysł nad kulturą

cyfrową koncepcje

m.in. J.-P. Sartréa czy

H. G. Gadamera. 
jak powinno sięinterpretować gry komputerowe. Zadawano m.in. pytania o to, czy w procesie interpretacji należy wykorzystywać narzędzia stosowane do formatów narracyjnych, czy może skupić się na konfiguracyjnych aspektach komputerowej rozgrywki, oraz do jakiego stopnia uprawnione jest „wyczytywanie" z gier komputerowych sensów transcendujących same gry'. Nie będę się tu zagłębiał w szczegóły sporu między ludologami a narratologiami, ponieważ nie chcę ani go wskrzeszać, ani retroaktywnie stawać w nim po którejś ze stron. Chcę natomiast przyjrzeć się pewnej części jego spuścizny metodologicznej, części najważniejszej dla wszystkich, którzy zajmują się hermeneutycznymi projektami dotyczącymi gier komputerowych, a konkretnie stanowisku zakładającemu, że gry komputerowe nie mogą być czytane tak jak teksty ani oglądane tak jak filmy, ale że ich badacz musi zająć pozycję gracza znajdującego się w centrum wydarzeń. Moglibyśmy to stanowisko nazwać „ludologiczną doktryną interpretacyjną" (ludological doctrine of interpretation), której metodologia została wyczerpana w sugestii Aarsetha, że „wszystko, co musimy zrobić, żeby pokazać, że rozumiemy grę, to dobrze w nią grać"2.

Chciałbym sprawdzić, czy „ludologiczna doktryna interpretacji” i program metodologiczny, który ona zakłada, są tak jasne, jak się to wydaje na pierwszy rzut oka, zwłaszcza w przypadku konfrontacji z materialnością (materiality) współczesnych jednoosobowych gier komputerowych. Moim zdaniem temu, co oznacza dla interpretacji fakt, że badacz stał się graczem, nie poświęca się wystarczająco wielu tekstów teoretycznych, a sama możliwość interpretowania nie stanowi przedmiotu teorii, tylko jest przyjmowana przez krytyków, twórców, badaczy, graczy i badaczy-graczy za oczywistość. Traktowanie możliwości interpretacji jako oczywistości jest w pewnym sensie jak zamknięcie procesu interpretacyjnego w czarnej skrzynce. W ten sposób implikuje się normatywne ontologiczne założenia dotyczące przedmiotu badań $\mathrm{i}$ jego genezy oraz maskuje się fundamentalne kwestie związków między materialnością, procesem (process) i subiektywnością, których nakładające się poziomy zwykliśmy zbiorczo określać rozgrywką.

1 Por. J.H Murray Hamlet on the Holodeck: the future of narrative in cyberspace, Simon\&Schuster/ Free Press, New York 1997, s. 144; M. Eskelinen The gaming situation, "Game Studies" 2001 No. 1, http://www.gamestudies.org/0101/eskelinen/ (31.05.2017).

2 E. Aarseth Badanie zabawy: metodologia analizy gier, przeł. M. Filiciak, w: Światy z pikseli. Antologia studiów nad grami komputerowymi, red. M. Filiciak, Wydawnictwo SWPS Academica, Warszawa 2010, s. 30. 
Do zagadnień dotychczas pomijanych przez „ludologiczną doktrynę interpretacji" należą m.in. następujące problemy: czym są te rzeczy, które nazywamy jednoosobowymi grami komputerowymi? czy mają one takie same zasady jak gry w ogóle? jakie są różnice w rozumieniu gier przez graczy, akademików i twórców? do jakiego stopnia powinno się brać pod uwagę intencje twórcy w procesie interpretacji jednoosobowej gry komputerowej? czy możliwe jest założenie, że gry jako przedmioty interpretacji zawierają pewne komponenty (features) nieprzewidziane przez ich twórców? jak poddać negocjacjom w działalności akademickiej spotkania z tego rodzaju komponentami? jeśli istnieje więcej niż jeden sposób na to, by zagrać „dobrze”, to czy (i jak) badacz może sformułować takie sądy na temat gry, które trafią do szerokiego grona graczy?

Rozważania rozpocznę od anegdotycznego przytoczenia mojego własnego doświadczenia z „pętlą śmierci” w New Vegas, zwracając szczególną uwagę na braki w teorii badania/grania, które to doświadczenie wydobywa. Dzięki tej analizie przejdę do dociekań na temat "growości" (gameness) jednoosobowych gier komputerowych, która uwydatnia specyficzny związek między materialnością i procesem w jednoosobowych grach komputerowych, nieistniejący w przypadku gier „tradycyjnych”. To z kolei pozwoli mi spojrzeć na różne podejścia do spotkań z materialnością jednoosobowych gier komputerowych i wyartykułować rozróżnienie między badaniem gier (game studies) a badaniem tworzenia gier (game design research). Wreszcie - by uzupełnić doktrynę ludologiczną - będę teoretyzował na temat możliwości stworzenia ram autentycznej interpretacji, gdzie interpretacja nie przebiega poprzez projektowanie jakiejś „istoty” (takiej jak „growość" albo „symulacja”) przedmiotu badań, a poprzez analizę materialnej gry takiej, jaką ona jest.

\section{„Pętla śmierci" w New Vegas}

W związku z tym, że jestem raczej typem gracza w Civilization ${ }^{3}$ (1991), a zatem takiego, który woli rozgrywkę turową od prowadzonej w czasie rzeczywistym oraz abstrakcyjne reprezentacje od trójwymiarowego fotorealizmu $\mathrm{z}$ antropomorficznymi postaciami, z początku byłem sceptycznie nastawiony do New Vegas. Moje wcześniejsze doświadczenia budziły obawę, że New Vegas uraczy mnie jedynie niemającym końca przeklikiwaniem się przez dialogi

3 Civilization jest grą strategiczną, wykorzystującą system turowy; mechanika rozgrywki tego typu gier jest silnie związana z modelem rozgrywki planszowej. 
przetykanym wyuczonymi i schematycznymi ćwiczeniami koordynacji ręka - oko. Jednakże obietnica ogromnego, otwartego na eksplorację świata oraz moje wcześniejsze zobowiązanie do napisania eseju (nie tego) o New Vegas były dostatecznie przekonywające, żebym spróbował. Kiedy już zszedłem z kanapy doktora Mitchella, zdecydowałem, że zamiast wykonywania zleconych misji wyruszę na poszukiwania tytułowego miasta. Wiązało się to z przemierzaniem terenów opanowanych przez agresywne stwory, rozmawianiem z górnikami spotykanymi po drodze, walką wręcz z niespodziewanie wrogo nastawionymi ludźmi w jakiejś przyczepie kempingowej itd.

Znalazłszy się pod murami New Vegas, zostałem naocznym świadkiem potyczki między strażnikami a buntownikami, w związku z czym szukałem schronienia w pobliskim motelu El Rey. Wbiegłem prosto do motelowego pokoju na parterze, tuż obok parkingu. Wtedy, w ułamku sekundy, użądlił mnie zmutowany skorpion drzewny, a jego jad zaczął powoli działać. Zaraz potem, czego z początku nie zauważyłem ze względu na to, że byłem zajęty skorpionami, artefakt gry zapisał automatycznie mój postęp, tak jak to zwykle robił w przypadku odkrycia nowej lokacji. Zdałem sobie sprawę, że nie byłem dosyć silny, by poradzić sobie ze stadem skorpionów; być może dlatego, że podczas tworzenia postaci przypisałem większość punktów do cech wpływających na społeczne interakcje z niegrywalnymi postaciami (NPC), jej umiejętności przydatne w walce były zasadniczo żadne. Niemniej jednak udało mi się wykończyć najbliższego skorpiona i uciec na parking, gdzie gra poinformowała mnie, że „czuję zawroty głowy”. Zauważyłem, że moje punkty zdrowia bardzo szybko spadały. Zmartwiony tym faktem zjadłem wszystkie jadalne rzeczy, które miałem przy sobie i zużyłem wszystkie Stimpaki, by odzyskać zdrowie, co jednak tylko opóźniło trochę moją nieuchronną śmierć.

Przeżywszy dzięki systemowi autozapisu wiele śmierci po drodze do motelu El Rey, nie martwiłem się tym zbytnio i pomyślałem, że będę musiał tylko rozegrać jeszcze raz niewielką część akcji. Jednakże od razu po wskrzeszeniu znalazłem się w sytuacji przypominającej poranek z Dnia Świstaka - walcząc ze skorpionem, którego dopiero co zabiłem, wychodząc z pokoju, „czując zawroty głowy", jedząc czekoladę i padając martwy na ziemię. Utknąłem tym samym w pętli śmierci. Zdałem sobie sprawę, że artefakt nadpisał wcześniejszy autozapis stanem gry z motelu El Rey. Mój poprzedni ręczny zapis powstał dużo wcześniej, po zabiciu trzech Prochowych Gangsterów na początku mojej drogi do New Vegas. Czułem się wówczas na tyle niepewny, że w ogóle robiłem jakieś ręczne zapisy. Jedynym sposobem - oprócz wpisania odpowiednich komend w konsolę, co odkryłem dopiero później - aby wyrwać się 
z pętli śmierci, było ponowne rozegranie całej drogi z przyczepy kempingowej położonej koło Goodsprings. Zirytowałem się.

Moją intencją była eksploracja New Vegas jako artefaktu, „narzędzia zaba$w^{\prime \prime 4}$ z pobudek czysto hedonistycznych. Dla mnie jako gracza pętla śmierci w oczywisty sposób stanowi wadę, ponieważ zmarnowałem przez nią kilka godzin miłego niedzielnego wieczora. Gdyby zdefiniować bug jako komponent programu, który zakłóca rozgrywkę wtedy, kiedy według logiki gry powinna ona pozostać niezakłócona, to pętla śmierci stanowiłaby słownikowy przykład na zawarty w grze bug. Być może powinno się także analizować ten fenomen w kontekście „wyłaniania się”, podobnego do wspinaczki po minach bezdotykowych ${ }^{6}$ w Deus Ex (2000) albo skakania za pomocą rakiet ${ }^{7}$ w Quake III Arena (1999), ale także różniącego się od tych przykładów ze względu na ewidentnie negatywne konsekwencje dla hedonistycznego projektu rozgrywki. Pętla śmierci jako wyłaniający się bug reprezentowała klęskę mojego hedonistycznego projektu.

Choć jako gracz byłem zawiedziony, jako akademik zacząłem opisywane zjawisko postrzegać jako co najmniej interesujące: całkowicie mnie pochłonęło, przypominając mi o moim skromnym miejscu w obiegu ludzko-technologicznym, który moglibyśmy nazwać rozgrywką; obiegu, w którym moja własna sprawczość mierzy się ze sprawczością technologii. Tym samym pętla śmierci legła u źródeł pewnego projektu krytycznego - ostatecznie doświadczyłem czegoś, dzięki czemu musiałem zmienić (jeśli nie całkowicie odrzucić) początkowe ramy hedonistycznej interpretacji i przypuszczenia, które

4 Por. np. S. Parkin Opinion: Touch Generations? Con Generations!, "Gamasutra. The Art \& Business of Making Games" 2008, czerwiec, http://www.gamasutra.com/ php-bin/news_index. php?story=19104 (31.05.2017); N. Adamo-Villani, K. Wright SMILE: an immersive learning game for deaf and hearing children, http://hpcg.purdue.edu/idealab/pubs/SIGGRAPH_2007.pdf (31.05.2017).

5 W tym sensie: każdy błąd oprogramowania, będący pochodną błędu człowieka w tworzeniu programu.

6 J. Juul The Open and the Closed: games of emergence and games of progression, w: Computer Games and Digital Cultures Conference proceedings, ed. by F. Mäyrä, Tampere UP, Tampere 2002, S. 325 .

7 J. Juul Half-real: video games between real rules and fictional worlds, The MIT Press, Cambridge 2005 , s. 81.

8 S. Giddings, H. Kennedy Little Jesuses and *@\#?-o_ robots: on cybernetics, aesthetics, and not being very good at lego star wars, w: The pleasures of computer gaming: essays on cultural history, theory and aesthetics, ed. by M. Swalwell, J. Wilson, McFarland, Jefferson 2008. 
ona za sobą niesie, m.in. założenie, że New Vegas to gra. Położenie, w którym się znalazłem, sprawiło, że jedyną rozsądną rzeczą, jaką pozostało mi zrobić, było podjęcie refleksji nad New Vegas i moim zaangażowaniem w procedurę rozgrywki, jak gdyby mechanika "kontr-gry" została z tego mainstreamowego tytułu AAA wyizolowana, tak jak gorąca kawa z pewnej produkcji studia Rockstar ${ }^{10}$.

Implikacje załamania się projektu hedonistycznego w momencie wystąpienia pętli śmierci były dla mnie zaskoczeniem ze względu na to, że na podstawie lektury kanonu groznawstwa myślałem, że interpretacja w przypadku gier komputerowych jest sprawą relatywnie prostą i pragmatyczną. Doświadczenie pętli śmierci ujawnia niedostatki ludologicznej doktryny w obliczu materialności artefaktów, które możemy nazwać jednoosobowymi grami komputerowymi. Ściślej mówiąc, nie da się za jej pomocą przedstawić świadectwa interpretacji takich artefaktów: można je rozumieć tylko do takiego stopnia, do jakiego mogą być opisane jako gry.

Jednym z możliwych rozwiązań byłoby przyznanie, że istnieją dwa poziomy interpretacji w trybie badania-grania: utylitarna interpretacja gracza, oparta na wstecznej inżynierii gry, mającej na celu zrozumienie tego, czym jest „dobra” rozgrywka, oraz właściwa akademikom analiza społeczno-kulturowa, za pomocą której próbuje się umieścić grę w szerszym kontekście znaczeniowym. Przykładowo Mosberg rozpoznaje podobne procesy i uważa je za temporalnie odrębne: „kiedy już gra została poznana i, przy odrobinie szczęścia, rozegrana z przyjemnością, wtedy można przyjąć wobec niej perspektywę bardziej analityczną"11. Sicart' ${ }^{12}$ odwołuje się do Finka ${ }^{13}$, żeby rozważać podobną kwestię: różnicę między wewnętrznym a zewnętrznym

9 A. Galloway Gaming - Essays on Algorithmic Culture, University of Minnesota Press, Minneapolis 2006, s. 125 .

Chodzi tu o modyfikację Hot Coffee do gry Grand Theft Auto: San Andreas (2004), która pozwala na dostęp do zawartej w kodzie programu (i bez modyfikacji nieaktywnej) pornograficznej minigry; nazwa pochodzi od "zaproszenia na kawę", które postać dostaje od spotykanych w grze kobiet.

S. Mosberg Between regulation and improvisation: playing and analysing "Games in the Middle", rozprawa doktorska, IT University of Copenhagen, Kopenhaga 2010, s. 52. M. Sicart Against procedurality, "Game Studies" 2011 No. 3 (11), http://gamestudies.org/1103/ articles/sicart_ap (31.05.2017). 
aspektem rozgrywki, z których pierwszy odwołuje się do relacji między cząstkami całości, zaś drugi - do znaczenia, jakie ma samo wydarzenie dla jego uczestników i obserwatorów. Powiązane rozróżnienie znajdziemy u Juula, który sugeruje, jakoby akcje w grach miały „podwójne znaczenie”, wskazując na dualizm rzeczywistych pionków poruszających się po planszy i np. armii gracza najeżdżających Skandynawię ${ }^{14}$.

Gdyby jednoosobowe gry komputerowe całkowicie uosabiały prototypowe właściwości „gier”, to należałoby domniemywać możliwość dokonania jasnego podziału między interpretacjami pierwszego i drugiego porządku czy też między znaczeniami wewnętrznymi i zewnętrznymi, słowem: koncentracji na „wnętrzu” gry bez potrzeby uwzględniania jej relacji ze światem zewnętrznym. Niemniej, jak sugeruje przykład pętli śmierci, materialność jednoosobowych gier komputerowych może być zaskakująco nie-growa. New Vegas jako materialny artefakt transcenduje przypisywaną mu definicję "gry" i tym samym jakakolwiek analiza, która zakłada podejście do niego właśnie „jak do gry” może jedynie częściowo naświetlić to, co szczególnie znaczące w incydencie z pętlą śmierci. Potrzeba zatem szerszych ram interpretacyjnych, by mówić o New Vegas w kontekście jego materialności.

Mimo że moja sytuacja z pętlą śmierci może być incydentem odosobnionym i, jako taka, także nie musi stanowić reprezentatywnego przykładu wszystkich doświadczeń jednoosobowej rozgrywki komputerowej w ogóle, to intuicyjnie wydaje się z natury intrygująca, w związku z czym warto ją zbadać nieco dokładniej. Być może „zepsucie się” gry w New Vegas podczas pętli śmierci mówi o czymś wcześniej niedostrzeganym w związku między grami i tymi rzeczami, które nazywamy "grami komputerowymi", i może to nieszczęsne zdarzenie da się wykorzystać do tego, by uwidocznić luki w istniejącej teorii groznawczej. Wydaje się możliwe, że tym, co psuje się w momencie wystąpienia pętli śmierci, jest komfort oferowany badaczowi-graczowi przez taką perspektywę badawczą, która zajmuje się wyłącznie analizą artefaktów w relacji do projektowanej istoty "gry", a zatem maskuje materialne komponenty niepasujące do tego ideału. Wygląda to na rozsądne założenie, zważywszy że ostatecznie jeśli jednoosobowe gry komputerowe uznamy za „narzędzia zabawy”, to możemy w heideggerowskim duchu przypuścić, że ich przejrzystość jako narzędzi zabawy (w tym samym sensie co transparentność młotka jako narzędzia wbijania gwoździ) staje się nieprzejrzystością dopiero po analizie ujawniającej ich materialności. Zatem tym, co chciałbym wnieść

14 J. Juul Half-real..., s. 141. 
do dyskusji o możliwości badawczej rozgrywki (research-play), jest uwzględnienie dróg, które otwierają się wtedy, gdy założenie "growości” lub jakiejkolwiek innej projektowanej istoty gry zostanie oddalone, a punktem skupienia badania jest materialność artefaktów jednoosobowych gier komputerowych: jednoosobowych gier komputerowych obecnych w związku między człowiekiem a techniką jako byty.

\section{Od gier do grywalnych artefaktów}

W tej sekcji dowodzę, że kwestię grywalności (playability) jednoosobowych gier komputerowych można postrzegać przez pryzmat specyficznego związku między materialnością a procesem. Co więcej, wykazuję, że podczas gdy materialności i proces są ze sobą powiązane także w grach transmedialnych, to w grach komputerowych przeplatają się do tego stopnia, że zostaje zakwestionowana możliwość rozdziału między nimi. Podkreślenie tego związku pozwala na wyprowadzenie trzech tez. Umożliwia określenie jednoosobowych gier komputerowych jako grupy wyróżniających się artefaktów, innych od tradycyjnych gier. Pozwala także odróżnić game studies jako praktykę od badań związanych z projektowaniem gier oraz zrozumieć tryby, w jakich można interpretować jednoosobowe gry komputerowe. Ów związek można zademonstrować poprzez analizę roli „zasad” w jednoosobowych grach komputerowych.

Relacja gier i zasad wydaje się zakorzeniona gdzieś między ontologią a językiem. Jako że mówimy o jednoosobowych grach komputerowych, to z oczywistych przyczyn można założyć, że zasady odnoszą się do znaczenia wydarzeń, przedmiotów i spotkań w obrębie gry wideo. W grach takich jak pasjans czy Monopoly i im podobnych zasady są czymś, co gracz musi zinternalizować i czego przestrzegać, żeby w ogóle grać. Po rozpoczęciu rozgrywki w Monopoly różnica między kapeluszem a butem służy głównie wyodrębnieniu reprezentacji poszczególnych graczy na planszy. Ta i inne formy specjalnego znaczenia kart, żetonów i innych tego rodzaju parafernaliów ma swoje źródło właśnie w zasadach.

Zasady, jeśli są przestrzegane, tworzą coś, co moglibyśmy nazwać - z braku lepszego słowa - „magią” spajającą jednię procesu grania, subiektywnego nastawienia tudzież „dyspozycji” ${ }^{15}$ graczy oraz materialnych obiektów

15 T. Malaby Anthropology and play: the contours of playful experience, "New Literary History" 2009 No. 40, S. 211. 
służących za akcesoria w grze. Jeśli tylko któryś z graczy konsekwentnie łamie zasady, gra się rozpada. Kiedy proces ustanie, jakiekolwiek znaczenie nadane przez zasady staje się wyłącznie potencjalne, konceptualizowane najlepiej jako wspomnienia rozegranej gry. Jeśli gracz wciąż przejawia zainteresowanie wspomnianym kapeluszem lub butem po zakończeniu tego procesu, to albo traktuje je jak pamiątki, albo zwyczajnie podobają mu się one ze względów indywidualnych, takich jak pozytywne skojarzenia z wszelkimi kieszonkowymi przedmiotami odlanymi w cynku. Możemy zatem dojść do wniosku, że w grach zasady odpowiadają za jednię materialności i procesu, która jest istotna dla graczy. Hotel postawiony na polu w grze Monopoly to przykład takiej jedni: ma materialny korelat, czerwony kawałek plastiku, oraz znaczenie w obrębie procesu rozgrywki i doświadczenia gry - nadaje graczowi prawo do pobierania potrójnej opłaty od tych, którzy na tym polu staną, oraz odczuwania z tego powodu schadenfreude. Gdy zaprzecza się zasadom, takie jednie ulegają rozpadowi.

Niemniej fenomen jednoosobowej rozgrywki komputerowej nie podlega procesowi rozpadu jako następstwu zmian w psychologicznym krajobrazie gracza: aspekty gier wideo istnieją w zupełnym oderwaniu od jego myśli, motywacji i intencji. Na przykład niezależnie od tego, co myślę o danej postaci NPC w New Vegas, pozostanie ona na moim ekranie jako postać NPC zajmująca się swoimi NPC-owymi sprawami i zakorzeniona w materialności - pikselach na monitorze, alokacjach rejestrów pamięci, bieżących fluktuacjach na płycie głównej, kwarkach, strunach itd., w zależności od preferowanego stopnia abstrakcji1 ${ }^{16}$.Żeby mówić o postaci NPC jako o postaci NPC nie można ani nie trzeba uwzględniać „zasad” wiążących ze sobą proces i materialność, bowiem zarówno proces, jak i materialność są trwale zapisane w danych. Nie ma „materialnej” postaci NPC odrębnej od postaci NPC funkcjonującej podczas rozgrywki w takim sensie, jak czerwony kawałek plastiku jest odrębny od hotelu w Monopoly. Podczas gdy Monopoly wymaga od graczy internalizacji zasad w celu utrzymania jedni między czerwonym plastikiem a „hotelowością", w New Vegas materialność i proces przeplatają się ze sobą do tego stopnia, że z perspektywy gracza są one nierozłączne jako sekwencje wykonywane przez program, więc tym samym „podwójne znaczenie” 17

16 Por. I. Bogost Alien Phenomenology, or, What It's Like to Be a Thing, Minnesota UP, Minneapolis 2012, S. 17.

17 Por. np. J. Juul Half-real..., s. 141. 
występuje w przypadku postaci NPC tylko o tyle, o ile ma je wszystko materialnie istniejące na świecie.

Jakiekolwiek wyobrażenie na temat „zasad” w opisie jednoosobowej gry komputerowej podczas rozgrywki jest rezultatem dobrowolnego wglądu w zachowanie programu. Może ono być np. częścią wypowiedzi ekspertki, która obserwowała zachowanie programu wystarczająco długo, by dostrzec konkretne wzory i dokonać własnych inferencji - poprawnych lub nie - odnośnie do zasad rządzących tym zachowaniem. Niemniej, jako że warunki w których program zachowuje się w dany sposób, tj. warunki niezbędne do przeprowadzenia rozgrywki, są określone w kodzie wykonywanym przez komputer, to „zasady", o których mówi ekspertka, są zasadniczo różne od „zasad" zinternalizowanych i przestrzeganych przez graczy Monopoly. „Zasady” ekspertki są środkiem, za pomocą którego komunikuje się jakąś informację o zachowaniu programu, nie zaś rzeczywistymi konstytuantami gry. „Zasady" niewiele różnią się od „zasad”, którymi meteorolog tłumaczyłby, dlaczego obszar o niskim ciśnieniu atmosferycznym zmienia się w obszar o wysokim ciśnieniu. Nawet jeśli zdarzyłoby się tak, że rzeczona ekspertka jest projektantką gry, o której mowa, to ontologiczny status „zasad” opisany powyżej nie zmienia się: chociaż możemy uznać „zasady” w opisie projektantki jako swoiste myślowe schematy, bez których jej praca byłaby niemożliwa do wykonania, to musimy zdać sobie sprawę z tego, że podczas przekładu gry z pomysłu projektantki na program komputerowy te „zasady" zostają bezpowrotnie utracone.

Chociaż niektórzy mogliby się zgodzić ze zdaniem, że gry typu transmedialnego są „zrobione z zasad" i że w badaniu jednoosobowych gier komputerowych koncepcja zasady może być użyteczna jako narzędzie opisu, to należy zauważyć, że taka koncepcja byłaby nie do utrzymania w charakterze sądu ontologicznego mówiącego o tym, czym są jednoosobowe gry komputerowe. Ponieważ zasady określają to, jak przedmioty postrzega się jako znaczące w grach tradycyjnych, zaobserwowanie braku zasad w jednoosobowych grach komputerowych sugeruje, że wytłumaczenie mechanizmu wyłaniania się znaczenia z zasad w grach tradycyjnych nie może zostać zastosowane w opisie tego procesu w jednoosobowej rozgrywce wideo. Zamiast tego proponuje spojrzeć na związek między procesem a materialnością, żeby naświetlić nieco kwestię możliwości znaczenia.

Odwoływałem się wcześniej do Giddingsa i Kennedy'ego, żeby zasugerować, że oprócz gracza ludzkiego także technologia posiada sprawczość w sytuacji rozgrywki. Walka między tymi dwiema sprawczościami, przejawiająca 
się w materialności gry komputerowej, jest tym, co odróżnia gry komputerowe od gier tradycyjnych. Pozwolę sobie rozwinąć tę ideę poprzez pojęcie oporu Sartre’a. Według niego opór jest tym, co czyni wolność możliwą: „wolny byt-dla-siebie może istnieć wyłącznie jako zaangażowany w świat, który stawia opór"18. Krótko mówiąc, opór jest tym, dzięki czemu możliwe jest rozróżnienie między życzeniem a wyborem. Gry i jednoosobowe gry komputerowe różnią się tym, jak ich materialne bycie reaguje na wybory gracza. Artefakty niezbędne do gry w Monopoly nie mogą zmieniać swoich właściwości materialnych, nie opierają się projektowi rozgrywki w Monopoly: konieczność zniszczenia wszystkich banknotów i tym samym niepozwolenia na kontynuowanie rozgrywki nie może wyłonić się z zasad Monopoly. Jeśli te banknoty podrą się w trakcie rozgrywki, to będzie to nieszczęśliwy wypadek, którego odpowiednikiem w kontekście „gier komputerowych” byłby brak zasilania. Te artefakty, które nazwaliśmy jednoosobowymi grami komputerowymi, często jednakże zmieniają własną materialność po to, by utrudnić lub wręcz uniemożliwić graczowi dalszą rozgrywkę. Wyświetlenie ekranu z napisem "game over", które w jednoosobowych grach komputerowych rozumiemy jako sytuację znaczącą, gdzie materialność zmieniła się do tego stopnia, że liczba dostępnych graczowi wyborów została zredukowana do zera, jest ostatecznym przejawem tego, co moglibyśmy nazwać oporem przeciwko projektowi rozgrywki. Uszczuplenie możliwych wyborów jest materialnym oporem, który artefakt przeciwstawia chęci rozgrywki graczki, tj. korzystania z jej wolności jako graczki.

Zarówno w grach tradycyjnych, jak i jednoosobowych grach komputerowych, gracze są obdarzeni pewnym zakresem wolności, czyli mają możliwość (i konieczność) wyboru między zaprezentowanymi opcjami. Kondycję graczki, która z definicji chce grać, charakteryzuje dualizm wolności i odpowiedzialności: gra daje jej wolność wyboru i jednocześnie czyni ją za tę wolność odpowiedzialną poprzez opieranie się jej projektowi rozgrywki. W innym tekście nazwałem to zjawisko „kondycją rozgrywki”19 i zauważyłem,

18 J.-P. Sartre. Byt i nicość, przeł. J. Kiełbasa, Zielona Sowa, Kraków 2007, s. 588.

O. T. Leino Understanding games as played: sketch for a first-person perspective for computer game analysis, w: Proceedings of the Philosophy of Computer Games Conference 2009, Oslo University, Oslo 2009, http://www.hf.uio.no/ifikk/english/research/projects/thirdplace/Conferences/proceedings/Leino\%20Olli\%20Tapio\%202009\%20-\%20Understanding\%20Games\%20 as\%2oPlayed\%20Sketch\%20for\%20a\%2ofirst-person\%2operspective\%2ofor\%2ocomputer\%20game\%2oanalysis.pdf. 
że można porównać ją z kondycją ludzką u Sartre'a ${ }^{20}$. Przyznaję, że gracze w Monopoly także są odpowiedzialni za wolność, którą się cieszą jako gracze w Monopoly, ale ciężar narzucania kondycji rozgrywki leży na ich barkach. W Monopoly kondycja rozgrywki nie posiada materialnych korelatów: plansza, pionki itd. nie mogą oprzeć się projektowi rozgrywki; materialność i proces są odrębne od siebie, spojone jedynie w wyniku przyjęcia zasad gry przez graczy. Gracze korzystający z automatu z flipperami będą natomiast poddani kondycji rozgrywki z materialnymi korelatami. Jeśli trafią w konkretne miejsce kulką, dostaną dodatkowe kulki, za pomocą których będą mogli trafić $\mathrm{w}$ więcej celów, niezależnie od tego, co sądzą o zasadach flipperów. Jeśli zaś pozwolą, by jedna z kulek przeleciała między łapkami, wtedy inne elementy planszy będą zachowywać się w sposób niekontrolowany, co jeszcze bardziej utrudni odbijanie kolejnych kulek. Można zatem stwierdzić, że „kondycja rozgrywki” nie odnosi się wyłącznie do rozgrywki ułatwionej przez komputery: „ani możliwość przeprowadzania szybkich kalkulacji przez urządzenie, ani wibrujące podzespoły z silikonowych monokryształów, które ono zawiera, nie są istotne dla tego, co nas zajmuje"21.

W świetle powyższej analizy przeżycie wobec oporu wpisanego w kondycję rozgrywki staje się osiągnięciem. Graczka odnosząca sukcesy to taka, która może zdecydować o tym, czy grać dalej, zaś graczka ponosząca porażkę staje w obliczu już dokonanego bez niej wyboru. Co więcej, zakończenie jednoosobowej rozgrywki komputerowej, które według Aarsetha może przypominać nagłe zwolnienie z pracy, koniec projektu, który chciałoby się kontynuować, nie współgra ze "zwycięstwem", jaki znamy z kontekstu tradycyjnych gier².

Nieco dziwne definicje sukcesu i porażki oraz niemożliwość aplikacji idei klasycznie pojmowanego „zwyciężania” potwierdzają, że rzeczy takie, jak jednoosobowe gry komputerowe, flipperowe automaty albo nawet niektóre przypadki „interaktywnych fikcji”, są gatunkiem innym niż gry tradycyjne. Woods rezerwuje pojęcie grania w grę dla aktywności społecznych, a do jednoosobowych gier komputerowych odnosi się jako do „zautomatyzowanych

J.-P. Sartre Byt inicość, s. 464

O.T. Leino Emotions in play: on the constitution of emotion in solitary computer game play, rozprawa doktorska, IT University of Copenhagen, Kopenhaga 2010, s. 165.

E. Aarseth Genre trouble: narrativism and the art of simulation, w: First Person: new media as story, performance, and game, ed. by N. Wardip-Fruin, P. Harrigan, The MIT Press, Cambridge 2004 , s. 51. 
wyzwań"23. Inni badacze także sugerowali, jakoby pojmowanie gier komputerowych jako gier w ogóle nie zawsze było najbardziej efektywnym podejściem. Kirkpatrick twierdził, że „to, co wyróżnia formę gry komputerowej, może być jedynie częściowo zrozumiane w procesie badania jej growego charakteru"24 oraz że ich estetyczna analiza powinna brać pod uwagę fizyczne cechy sytuacji rozgrywki, zaś Aarseth i Calleja nazwali gry komputerowe „przedmiotami skonglomerowanymi”25, składającymi się nie tylko z komponentów ludycznych, ale także narracyjnych i innych. Przypomnijmy sobie także stanowisko Sudnowa, który pisząc o tym, co można by uznać za uzależnienie od gry Breakout!, zauważał, że Atari zdecydowało się nazwać swoje produkty „«grami» wideo tylko po to, żeby uniknąć kłopotów z FDA"26. Woods sugerował, że formy rozgrywki możliwe dzięki komputerowi są nie tylko rozszerzonymi formami rozgrywki tradycyjnej, ale „całkiem nowymi sposobami rozgrywki, które być może jedynie ze względu na konwencję zostały określone jako gry"27. Żeby utrzymać jakiekolwiek znaczenie pojęcia "gry", warto zachować je dla tych zjawisk, które składają się z zasad itp. oraz znaleźć bardziej słowa bardziej adekwatne do opisu rzeczy takich, jak New Vegas albo flippery. Terminologiczne wyklarowanie, pozwalające uznać specyfikę jednoosobowych "gier" komputerowych, powinno nastąpić już dawno temu.

Wśród cech wspólnych łączących np. automat flipperowy Terminator 2: Judgement day (1991), jednoosobową grę komputerową, taką jak New Vegas albo Tetris (1989), oraz „interaktywną fikcję” w rodzaju Dragon's Lair (1983) jest taka, że wszystkie one są technologiami, a być może konkretniej: te c h nologiczny mi artefakta mi. Charakterystycznym dla tego rodzaju artefaktów jest to, że są one „multistabilne”, tj. niebędące tym, czym tak naprawdę są, dopóki nie znajdą się w zasięgu ludzkiej praxis i często posiadające

23 S. Woods (Play) Ground rules. The social contract and the magic circle, "Observatorio" 2009 No. 1 (3), s. 13, http://obs.obercom.pt/index.php/obs/article/view/243 (31.05.2017).

24 G. Kirkpatrick Between Art and Gameness: Critical Theory and Computer Game Aesthetics, "Thesis" 2007 No. 89, s. 75.

E. Aarseth, G. Calleja The word game: the ontology of an undefinable object, wykład wygłoszony podczas konferencji Philosophy of Computer Games 2009, University of Oslo, Norway, 13 sierpnia 2009, http://www.hf.uio.no/ifikk/english/research/projects/thirdplace/Conferences/video/02_aarseth_1200.mov (31.05.2017).

D. Sudnow Pilgrim in the Microworld. Eye, mind and the essence of video skill, Warner Books, New York 1983, s. 8. 
wiele potencjalnych zastosowań ${ }^{28}$. Konceptualizacja New Vegas i innych jako technologii wiąże się z uznaniem ich multistabilności.

$\mathrm{Z}$ jednej strony można dzięki temu zwrócić uwagę na to, że określenie przedmiotu badań jako „jednoosobowe gry komputerowe” mogłoby narzucać szereg presupozycji odnośnie do tego, jak te obiekty mogą i powinny być używane. Weźmy pod uwagę np. grę komputerową Monopoly 3 (2002), która przypomina rozgrywkę w planszowy oryginał i mogłaby nawet być określona jako jej "symulator". Jednakże Monopoly i Monopoly 3 są „tą samą grą" jedynie w opisie, który ujawnia właściwości Monopoly 3 tylko do tego stopnia, w jakim ucieleśnia ono zasady Monopoly albo "symuluje" rozgrywkę w Monopoly. Opis Monopoly 3 jako Monopoly wiązałby się ze zignorowaniem jego materialności technologicznej i ustawiałby kontekst użycia tradycyjnego Monopoly jako najważniejszy spośród kontekstów użycia.

$\mathrm{Z}$ drugiej strony, ponieważ prawie wszystko może znaleźć się w zakresie ludzkiej praxis i stać się technologią, to opieranie definicji na "technologii” stanowi ryzyko transformacji przedmiotu badań w niedookreślony kłąb znany z tradycji Object-Oriented Ontology ${ }^{29}$ : katamari, w którym gry komputerowe grzęzną wśród śrubokrętów, pochłaniaczy wilgoci, arkuszy kalkulacyjnych, dźwigni i równi pochyłych, zjednoczone ze sobą jedynie w imię „technologii" ${ }^{\prime \prime}$. I choć nie ma nic złego w takich niedookreślonych kłębach, to jako że naszym celem jest dostrzeżenie technologicznej specyfiki jednoosobowych gier komputerowych, definicja przedmiotu badań powinna zawierać te właściwości jednoosobowych gier komputerowych, które wyróżniają je spośród innych technologii.

Być może zamiast mówić o jednoosobowych grach komputerowych albo artefaktach technologicznych w ogóle, należałoby mówić o gryw al ny ch a r te fa k t a ch (playable artifacts) rozumianych następująco: grywalne artefakty odróżnia od gier brak możliwości odseparowania procesu i materialności oraz dają się one określić jako podgrupa wszystkich technologicznych artefaktów ze względu na ich możliwość oceny wyborów użytkownika, dzięki

D. Ihde Technology and the Lifeworld: From garden to earth, Indiana UP, Bloomington 1990.

Nurt filozoficzny związany także z realizmem spekulatywnym, znoszący prymat istnienia człowieka nad istnieniem przedmiotów; lan Bogost odpowiada za przeszczepienie go na grunt teoretycznej refleksji w badaniu gier.

Por. np. I. Bogost Alien phenomenology, or, what it's like to be a thing, Minnesota UP, Minneapolis 2012, I. Bogost Videogames are a Mess, wykład ekspercki podczas konferencji DiGRA 2009, Uxbridge, Wielka Brytania, 1-4 Września 2009. 
której odpowiednio otwierają albo ograniczają kolejne wybory; innymi słowy przez ich możliwość narzucenia użytkownikowi kondycji rozgrywki. Należy zaznaczyć, że ta definicja nie narzuca kontekstu użycia, ale jest deskryptywnym zapisem właściwości materialnie istniejącego przedmiotu: można bez obaw powiedzieć, że grywalny artefakt je st taki lub inny, bez potrzeby negocjacji niedookreślonych związków procesu z materialnością albo idei $\mathrm{z}$ bytami, jak to ma miejsce w przypadku gier transmedialnych.

Niezależnie od wzmiankowanych różnic między grami a grywalnymi artefaktami nierozsądne byłoby zignorowanie popularności kolokwialnego sformułowania o "grze w jednoosobową grę komputerową", które z pewnością rezonuje z odczuciami towarzyszącymi temu doświadczeniu. Trzeba zatem zaznaczyć, że choć analiza jednoosobowych gier komputerowych jako i s tn i e ją c y ch eliminuje kwestię esencji "growości”, to jednak nie zakłada eliminacji przebytego doświadczenia tego, co ktoś mógłby określić jako "grywalność" (przez co, być może, doszedłby do idei growości). Traktowanie jednoosobowej gry komputerowej, takiej jak Monopoly 3, jako grywalnego artefaktu nie jest równoznaczne ze stwierdzeniem, że główny, najpopularniejszy albo pod wieloma względami najbardziej znaczący kontekst użycia Monopoly 3 nie odnosiłby się do tego, co wiemy o rozgrywce w tradycyjne Monopoly. Mówiąc prosto: mimo że grywalne artefakty nie są grami, to oferują doświadczenia podobne do doświadczeń rozgrywki w tym sensie, że w obydwu przypadkach człowiek jest odpowiedzialny za własną wolność jako gracz. To doświadczalne podobieństwo otwiera wiele ścieżek dla refleksji badawczej. Przykładowo można zwrócić uwagę na implikacje responsywnej technologicznej materialności uobecnionej w różnicach między rozgrywką, na którą pozwala komputer, a rozgrywką, na którą pozwala chociażby zestaw kart i pionków na planszy. Należy jednakże zauważyć, że akademicka refleksja o Monopoly ,jako grze" będzie pełna presupozycji. W następnej sekcji rozwinę tę kwestię, żeby określić stopień, do którego te presupozycje można uzasadnić w innych celach.

\section{Badanie projektu rozgrywki}

Sartre twierdził, że częścią kondycji wolnego człowieka jest potrzeba „uczy-

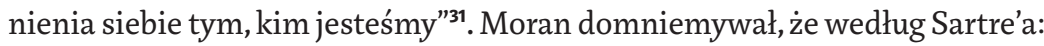


Nie istnieje schemat dla ludzkiej egzystencji [...]. Musimy raczej zmierzyć się z oszałamiającym brakiem formy i niezakorzenieniem naszej egzystencji. [...] Jedyne możliwe znaczenie, jakie ma życie, to to, które nadaje się mu przez przeżywanie, a zatem wyzwanie życia autentycznego jest najwyższym ludzkim wyzwaniem ${ }^{32}$.

U Sartre'a autentyczność stoi w opozycji do nieautentyczności albo, dokładniej, ,złej wiary”, będącej swojego rodzaju samo-zwodzeniem, w wyniku którego np. ze względu na zewnętrzną presję jednostka zaprzecza konieczności wolności, czyli wyboru między zaprezentowanymi możliwościami ${ }^{33}$. Chociaż oczywiście świat jest światem, a New Vegas grywalnym artefaktem, to wydaje się, że koncepcje autentyczności i złej wiary mogą naświetlić modalności interpretacji, które umożliwia New Vegas. Wydaje się również, że różnica między autentycznością a złą wiarą może pomóc zrozumieć różne motywacje stojące za poszczególnymi podejściami badawczymi do grywalnych artefaktów. Pochylmy się nad tym zagadnieniem.

Możemy opisywać New Vegas jako pozwalające graczce na „stwarzanie siebie" wobec grywalnego artefaktu: może ona stawiać przed sobą pewne projekty i dzięki oporowi artefaktu New Vegas być właściwie odpowiedzialna za swoje wybory. Ja na przykład chciałem przedsięwziąć projekt eksploracji New Vegas, więc zszedłem z kanapy Doktora Mitchella i wyruszyłem w podróż przez zdradzieckie tereny, umarłem kilka razy, zostałem wskrzeszony, dotarłem do motelu tuż pod murami miasta, zostałem autozapisany i użądlony przez skorpiona, a potem utknąłem w pętli śmierci. Dla mnie jako dla gracza New Vegas jest grą i nauczyłem się już całkiem sporo o zasadach, „według których" wydaje mi się, że ona operuje, i jestem w stanie formułować przypuszczenia o tym, jak ona działa. Przypuszczam, że przyjmowanie questów jest ważne, że dialog zawiera istotne informacje i mógłbym nawet przyjąć kargistyczny tryb interpretacyjny, uznając, że artefakt zachowuje się według spójnego zestawu zasad.

Z początku mogłoby się wydawać, że pętla śmierci stwarza problem dla tego rodzaju interpretacji, ponieważ nie ma ona żadnego sensu w obrębie świata New Vegas. Wiedząc, jak skomplikowane są dzisiejsze gry, biorę pod uwagę w analizie pętli śmierci możliwość, że projektanci gry popełnili błędy. Zwłaszcza komponenty działające wbrew zakładanej „logice gry” tudzież

D. Moran Introduction to phenomenology, Routledge, London-New York 2000, s. 362. 
„diegezie" przypominają mi o tej możliwości. Pętla śmierci może być dziwaczną anomalią, ale nie jest efemerycznym glitchem, takim jak wizualny artefakt spowodowany zatorem w rurociągu renderingu graficznego. Pętla śmierci stwarza następstwa dla mojego projektu rozgrywki, a jej źródła są doskonale wyobrażalne, być może sprowadzalne do potknięcia w procesie kontroli jakości. Jako gracz, traktując artefakt New Vegas jako grę, mogę wziąć w nawias jej multistabilność, wykluczyć wszystkie możliwe pozostałe użycia pętli śmierci i przypisać jej znaczenie buga. Przyjmuję zatem założenia nie tylko o zasadach zaimplementowanych w programie, ale także o zasadach będących intencją twórców, tym samym więc przedmiot mojej próby interpretacji jest o wiele większy niż New Vegas takie, jakie jest samo w sobie i wobec jakiego ja sam się stwarzam.

W tym utylitarnym trybie interpretacji dokonuję wstecznej inżynierii artefaktu w celu określenia, co twórcy chcieli, żebym zrobił w konkretnym momencie. Nie stwarzam się wobec artefaktu takiego, jakim on jest, ale poddaję się temu, co myślę, że powinienem zrobić. W rezultacie jako gracz przyjmuję, że pod powierzchnią materialności New Vegas istnieje jakiś „plan mojej egzystencji"34, umieszczony tam przez projektantów wielki schemat rzeczy, poprzez które powinienem interpretować wydarzenia, przedmioty i spotkania.

Stwierdzenie, że gracze w gry komputerowe praktykują wsteczną inżynierię, nie jest stwierdzeniem dotyczącym preferencji indywidualnego gracza ani sugestią, że niektórzy gracze mogą w ten sposób postępować. Kategorie Bartle'a ${ }^{35}$ nie muszą zostać uzupełnione, by zawierać typ gracza dokonujący wstecznej inżynierii. Ja jedynie czynię obserwację na temat tego, co znaczy grać w grę komputerową: żeby przeżyć jako gracz, ja, ty i my wszyscy musimy odkryć, co twórcy chcieli, żebyśmy robili w grze. Jeśli nam się to nie uda, wtedy najprawdopodobniej albo utkniemy, albo staniemy twarzą w twarz z ekranem "game over". Zatem jako gracz przypominam osobę przypisująca religijne znaczenie zbiegom okoliczności, interpretującą świat nieautentycznie i w złej wierze, wpisując wszystko, co dzieje się dookoła, w boski plan. Moja religijna rozgrywka wytrzymuje zakład Pascala, ponieważ poprzez dokonywanie wyborów zgodnych z przyjętym planem jestem nagradzany na wiele sposobów, np. informacją o przejściu questa albo odznakami za osiągnięcia różnego rodzaju.

D. Moran Introduction to phenomenology..., s. 362.

35 Por. R. Bartle Gracze, którzy pasują do MUD-ów, przeł. P. Zająkała, w: Światyz pikseli..., s. 363-408. 
Ten utylitarny tryb interpretacji charakteryzuje „rozgrywkę” w New Vegas w stylu oficjalnie usankcjonowanym przez odznaki i tym podobne rzeczy. Ważnym i aktualnym pytaniem, przypominającym te zadane przez Sicarta ${ }^{36}$ w jego krytyce proceduralizmu jest to: czy niuanse tego rodzaju aktywności, charakteryzowanych przez wsteczną inżynierię intencji twórcy, wychodzącą od często dysfunkcyjnej materialności, mogą być ujęte w pojęciu rozgrywki, które często uważa się za implikujące, jeśli nie społeczny wymiar, to przynajmniej wolne skojarzenia i wyobrażenia. Paralele Woodsa między jednoosobowymi grami komputerowymi a rozwiązywaniem sudoku albo wspinaczką górską ${ }^{37}$ wydają mi się tu istotnym kontekstem. Kolejną kwestią jest to, czy ta konkretna perspektywa interpretacyjna nie stwarza problemów dla badania gier.

Mimo że perspektywa utylitarna i nieautentyczna jest dla mnie w oczywisty sposób użyteczna jako dla gracza, to jednak wykrzywia ona nieco moją interpretację, ponieważ niesie ze sobą pewien rodzaj „błędu intencji autora”38. Podczas gdy błąd intencji autora odnosi się do założenia, że znaczenie tekstu może zostać odkryte poprzez znajomość jego intencji, to być może ten błąd w rozgrywce mógłby być opisany podobnie jak to, co Ihde nazwał „błędem twórcy”: „przekonanie, że twórca może zaprojektować w obrębie technologii jej cele i sposoby użycia" ${ }^{\prime 39}$. Na przykład, jeśli taktyka działająca gdziekolwiek indziej w New Vegas według założonych zasad nie działa w konkretnej lokacji, kuszące byłoby wyciągnięcie wniosku o odkryciu buga. Ta linia argumentacji stwarza problemy nie tylko dlatego, że na podstawie zbioru wypadków uzurpuje sobie dostęp do istoty, ale także dokładniej dlatego, że zakłada istnienie pod powierzchnią artefaktu gry „idealnej”, która według in te n cji t wó r c ó w miała działać bez „bugów” niepasujących do przyjętego zestawu zasad. Nieistnienie tej idealnej gry ${ }^{40}$ stwarza pewien problem: jeśli pozwolimy sobie na interpretację jednoosobowych gier komputerowych takimi, $\mathrm{j}$ a ki mi o ne

36 M. Sicart Against procedurality...

\section{S. Woods (Play)Ground rules...}

Por. np. W. Wimsatt, M.C. Beardsley Błąd intencji, w: Teorie literatury XX wieku. Antologia, red. A. Burzyńska, M.P. Markowski, Znak, Kraków 2006; R. Barthes Śmierć autora, przeł. M.P. Markowski, „Teksty Drugie” 1999 nr $1 / 2$.

D. Ihde Ironic technics, Automatic Press/VIP, Birkerød 2008, s. 19.

O.T. Leino Emotions in play..., s. 119; E. Aarseth „Define Real, Moron!"Some remarks on game ontologies, w: DIGAREC Keynote-Lectures 2009/10, ed. by S. Günzel, M. Liebe, D. Mersch, Potsdam UP, Potsdam 2011, s. 66. 
n i e s ą, to wydaje się tylko kwestią preferencji uznanie, że Tetris jest grą o życiu na przedmieściach ${ }^{41}$.

Ihde $^{\mathbf{4 2}}$ używa za Pickeringiem ${ }^{\mathbf{4 3}}$ pojęcia „tańca sprawczości”, żeby w realistyczny sposób opisać, jak wiele podmiotów, m.in. twórcy i konsumenci, negocjuje własne spotkania z oszałamiającym brakiem formy istnienia. Taniec sprawczości odnosi się do tego, jak autorska kontrola odbija się między wieloma projektantami, ogółem odbiorców i socjokulturowym kontekstem otaczającym stwarzany przedmiot w procesie wytwórstwa rzeczy takich, jakimi ostatecznie są. Ihde stawia tezę, że pojedyncze technologie „wydają się potencjalnie zawierać wiele użyć lub trajektorii rozwoju"44 iże „intencja twórcy może zostać odwrócona, stać się marginalna albo w ogóle nie mieć związku z ostatecznymi formami użytkowania"45. Zwrócenie uwagi wyłącznie na jeden tryb użytkowania albo trajektorię rozwoju przyjęte jako intencje twórcy, np. na oficjalnie usankcjonowane style rozgrywki, byłoby uzasadnione tylko wtedy, gdyby celem analizy było po prostu dalsze podążanie własną, projektowaną ścieżką rozgrywki w oficjalnie usankcjonowanym trybie, tj. „granie”, albo rozwój rzemiosła wytwarzania technologii ułatwiających usankcjonowane tryby rozgrywki, tj. „badanie tworzenia gier”.

Badacz tworzenia gier i gracz są podobni w tym sensie, że obydwaj stosują ludologiczną doktrynę: dokonują wstecznej inżynierii gry, żeby znaleźć schemat istnienia gracza. Bliska relacja graczy i twórców odbija się w tekstach dotyczących projektowania gier. Pedersen sugeruje, że studiowanie istniejących gier i granie w "gry od najlepszych do prawie najlepszych" jest potrzebne, żeby uzyskać dostateczną podstawę tworzenia gier w praktyce ${ }^{46}$, zaś Fullerton, Swain i Hoffman nawet bardziej dobitnie twierdzą, że „rolą twórcy gry jest, po pierwsze i najważniejsze, bycie adwokatem gracza. Twórca gry musi patrzeć na świat gier oczami gracza" ${ }^{47}$. Z perspektywy zarówno gracza, jak

41 Por. J.H. Murray Hamlet on the Holodeck..., s. 144.

42 D. Ihde Ironic technics..., s. 24.

43 A. Pickering The mangle of practice: time, agency and science, University of Chicago Press, Chicago 1995.

D. Ihde Ironic technics..., s. 24.

Tamże, s. 22.

R.E. Pedersen Game design foundations, Jones\&Bartlett Learning, Burlington 2009, s. 89.

47 T. Fullerton, C. Swain, S. Hoffman Game design workshop: a playcentric approach to creating innovative games, Morgan Kaufmann, Waltham 2008, s. 2. 
i twórcy, jak najbardziej sensownie jest traktować New Vegas jak grę i przenosić nań tym samym cały szereg koncepcji, takich jak np. występowanie bugów, czy normatywnych przypuszczeń, np. że gry stwarza się po to, by użytkownik dobrze się bawił. Jednakże, jak już wykazałem, implikuje to wiele uproszczeń dotyczących autorskich korzeni artefaktu i czyni go z multistabilnego takim, który ma już predefiniowany tryb użytkowania.

Konwencjonalne albo może raczej kuhnowskie ${ }^{48}$ "normalne" badanie tworzenia gier, które wciąż doskonali swoje narzędzia, by zawsze produkować „jeszcze lepsze” gry w obrębie ogólnie przyjętego paradygmatu, może uznać komponenty funkcjonalne za komponenty estetyczne. Weźmy np. grę dysfunkcyjną, która nieważne jak dobrym jest „dziełem sztuki”, jawi się jako zwyczajnie „zła” gra z perspektywy konwencjonalnego tworzenia gier. Z perspektywy groznawstwa byłoby to porównywalne do nazwania dadaistycznych publikacji Tristana Tzary „złymi książkami”, ponieważ ich niekonsekwentnie sformatowane i nieregularne linijki tekstu nie wpisują się w konwencję tradycyjnej literatury.

Groznawstwo od długiego czasu utrzymuje bliskie stosunki z badaniem tworzenia gier, nawet jeśli ten związek rzadko się uwidacznia. Niemniej wyznaczenie granicy między tymi dwiema praktykami jest niezwykle istotne, zwłaszcza jeśli chodzi o grywalne artefakty usytuowane na granicy tego, co uznajemy za akceptowalne ze względu na konwencje gier komputerowych. Podejście, które zamiata pod dywan bugi, glitche i inne dysonanse w poszukiwaniu wyobrażonej harmonii, która jeśli w ogóle istniała, to być może jedynie w domniemanym umyśle twórcy, pozwala widzieć przyszłość bardziej artystycznych podejść do tradycji gier komputerowych (np. jakichkolwiek prób wprowadzania "kontr-gier”, opisanego przez Galloway ${ }^{49}$ jako gier, które mają na celu krytyczną autorefleksję chociażby poprzez kreatywne wykorzystanie glitchów) w ciemnych barwach.

Na szczęście, w związku z tym, co już zostało powiedziane, projekty badania tworzenia gier i groznawstwa mogą być opisywane jako oddzielne. Dopóki nie zajmuję się badaniami tworzenia gier, dopóty przedmiotem moich badań nie jest "gra idealna”, tj. domniemana intencja domniemanego twórcy, wątpliwie manifestująca się w grywalnym artefakcie, ale istniejący w świecie grywalny artefakt. Eskelinen wymienia „narratologię drukowanego

\footnotetext{
48 T. Kuhn The Structure of Scientific Revolutions, University of Chicago Press, Chicago 1996.

49 A. Galloway Gaming..., s. 125.
} 
tekstu, teorię hipertekstu, filmoznawstwo i teatrologię"50 jako tradycje, które nie mają bezpośredniej aplikacji w przypadku gier komputerowych. Do listy Eskelinena moglibyśmy dodać badanie tworzenia gier i odnotować, że akademicka interpretacja New Vegas jako gry nie różniłaby się od wcześniejszych „prób kolonizacji”1 obecnych w historii badania gier.

Odrzucenie łączności badania tworzenia gier i groznawstwa uwalnia akademicką refleksję nad grami od ciężaru założeń, które mogłyby być przydatne w tworzeniu gier (np. istnienia zasad, celów, wyzwań, dobrej zabawy) ale wydają się zbyt redukcjonistyczne i normatywizujące z perspektywy z tworzeniem gier niezwiązanej. W autentycznym spotkaniu z pętlą śmierci jesteśmy zgubieni i nie znajdujemy wytłumaczenia: z perspektywy niezwiązanej z tworzeniem gier, która nie przyjmuje nieuzasadnionych założeń odnośnie do źródeł autorskich, możemy jedynie postrzegać pętlę śmierci jako oszałamiający brak formy, czysty i prosty, który należy przyjąć jako komponent, niezależnie od tego, jak niewygodne by to było, znajdujący się wśród innych komponentów artefaktu, z którym my wszyscy, jako gracze i badacze, musimy sobie poradzić. Jeżeli chcielibyśmy go „zrozumieć”, musimy wyjść poza projektowaną esencję, pogodzić się z faktem, że grywalny artefakt znany jako New Vegas nie istnieje jako gra, ale po prostu istnieje.

Odcięcie się od projektowanej esencji „growości” wydaje się objaśniać także badanie tworzenia gier, pozwalając na nakreślenie paraleli między grami a sztukami wizualnymi opartymi na czasie. Wykorzystują one częstokroć losowość, przypadek i nierówności materiału ${ }^{52}$, a działania te doprowadziły do odsunięcia praktyki od kultu artysty jako wirtuoza posiadającego całkowitą kontrolę nad materiałem plastycznym. Być może spotkania z oszałamiającym brakiem formy, jakim jest New Vegas, mogą wydobyć na światło dzienne rozbieżność między badaniem gier a badaniem tworzenia gier, ale także zapraszają do namysłu nad podstawą bardziej interesujących badań tworzenia gier, których nie ogranicza projektowana esencja „growości”. Być może dało się, projektując grywalne artefakty, przyjąć strategie w kreatywny sposób wykorzystujące „taniec sprawczości” materialności, graczy i twórców,

50 M. Eskelinen Towards computer game studies, w: First person: new media as story, performance, and game, ed. by N. Wardip-Fruin, P. Harrigan, The MIT Press, Cambridge 2004.

E. Aarseth Computer game studies, year one, "Game Studies” 2001 No. 1, http: //gamestudies. org/0101/editorial.html (31.05.2017).

E. Ham Randomness, Chance, \& Art, w: Handbook of Research on Computational Arts and Creative Informatics, ed. by G. Vincenti, G. Trajkovski, IGI, Hershey 2009. 
zamiast próbować ustrukturyzować go konwencjonalnymi choreografiami narzucającymi "kult indywidualnego twórcy" ${ }^{53}$, czyli w naszym przypadku twórcy rzekomo zdolnego do ujarzmienia niepodważalnie dysfunkcyjnej technologicznej materialności, która i tak zawsze będzie przywracać swoją sprawczość poprzez pętle śmierci i tym podobne.

\section{Egzystencjalna hermeneutyka New Vegas}

Jak dotąd udało mi się ustalić, że grywalne artefakty są znacząco różne od gier ze względu na związek materialności i procesu, który możemy opisać w przypadku grywalnych artefaktów, ale nie gier. Postawiłem tezę, że postrzeganie grywalnych artefaktów jako gier jest przydatne zarówno w kontekście rozgrywki, jak i projektowania tych artefaktów, ale nie da się uzasadnić takiej perspektywy w samych badaniach gier, oraz że projektowanie interesujących grywalnych artefaktów skorzystałoby na dekonstrukcji całego rusztowania "growości". Podczas gdy dyskusja na temat implikacji tej tezy dla badania tworzenia gier zasługuje na własny esej, pozostaje jeszcze zgłębić kwestię możliwości autentycznej interpretacji (tj. takiej, która nie ucieka się do projektowanych esencji albo np. „growości” zawartej w ludologicznej doktrynie czy "symulacji” pochodzącej z tradycji retoryki proceduralnej) zakorzenionej w materialności grywalnych artefaktów, a jednocześnie rezonującej ponad subiektywnością jednostkowego badacza. Jako że wielu z nas posiada bezpośrednie, doświadczalne dowody odbioru grywalnego artefaktu jako rzeczy znaczącej i ponieważ dotychczasowa analiza wykazała, że opis doświadczenia tradycyjnych gier jako dających przypisać sobie znaczenie nie może być przeniesiony na analizę gier komputerowych, pozostaje pytanie: jak na podstawie autentycznej analizy materialnej egzystencji grywalnych artefaktów opisać sposoby, w jakie przypisują one znaczenia wydarzeniom, przedmiotom i spotkaniom w obrębie ich samych?

Nauczenie się tego, jak przeżyć w New Vegas, jest równoznaczne z nauczeniem się, jak rozróżniać to, w co można wątpić, od tego, w co trzeba wierzyć. Taki rozwój przypomina to, jak, dorastając, uczymy się radzić sobie i wchodzić w interakcje z innymi przedmiotami. Według Sokolowskiego:

Kiedy odkryjemy,że popełniliśmy błąd, stopniowo wprowadzamy wymiary iluzji, pomyłki, oszustwa albo „zaledwie" pozoru. Stopniowo uświadamiamy

D. Ihde Ironic technics..., s. 
sobie, że rzeczy nie zawsze są takimi, jakimi się wydają; w grę zaczyna wchodzić rozróżnienie między istnieniem a wydawaniem się $e^{54}$.

Przykładowo, chociaż konstelacje jednostkowych drzew obszaru Pustkowia Mojave w New Vegas często pomagają odnaleźć się w przestrzeni, to jakakolwiek wiedza na temat rodzajów drzew w krajobrazie jest zarówno bezpośrednio, jak i pośrednio nieważna dla mojego przeżycia; pod żadnym konkretnym gatunkiem drzew nie znajdują się potencjalnie użyteczne przedmioty. Z drugiej strony różnice między nabojami są dla mnie niezwykle istotne: posiadanie w ekwipunku tylko nabojów typu .357 i pistoletu kalibru $9 \mathrm{~mm}$ w ewidentny sposób czyni mnie niezdolnym do obrony. Nic się nie stanie, jeśli będę myślał o drzewach jak o „zaledwie pozorach”, ale konsekwencje dotyczące takiego postrzegania naboi są śmiertelne.

Mimo że drzewa nie mają żadnego specjalnego znaczenia dla mnie jako dla gracza w New Vegas, to mogę niektóre gatunki darzyć szczególnym uczuciem - być może przypominają mi one białe brzozy północnoeuropejskiego krajobrazu, do którego przywykłem, i w związku z tym mogę chętnej przebywać na takich obszarach, na których te konkretne drzewa często występują. Ktoś z biografią podobną do mojej mógłby podzielać to skojarzenie i rozumieć moją preferencję, ale niemądrze byłoby przypuszczać, że rzecz ma się w tak samo z większą częścią graczy w New Vegas. Z kolei przekonanie o tym, że kule typu .357 pasują do Magnum .357, a nie do pistoletu $9 \mathrm{~mm}$, jest już podzielane przez większość - jeśli nie wszystkich - graczy. Możemy sformułować takie przypuszczenie, ponieważ choć nic się nie dzieje, jeśli moje przekonania dotyczące brzozowych sobowtórów są odmienne, to grywalny artefakt $\mathrm{New} \mathrm{Ve}$ gas użyje identycznych środków oporu wobec każdego gracza, by naprostować jakąkolwiek nieprawidłową interpretację zjawiska kompatybilności nabojów.

Tym samym ujawnia się sposób rozróżnienia dwóch typów interpretacji grywalnych artefaktów. Interpretacje idiosynkratyczne to takie, które nie są narzucone przez materialność grywalnego artefaktu, zaś interpretacje intersubiektywne są już przez tę materialność podyktowane graczom, czyli tym, których chęć grania jest wystarczająco silna, by przeżyć opór stawiany przez grywalny artefakt projektowi rozgrywki. Moja interpretacja brzozowatych drzew w New Vegas jako pięknych jest tym samym idiosynkratyczna, zaś moja interpretacja naboi typu .357 jako niepasujących do pistoletu $9 \mathrm{~mm}$ jest intersubiektywna. Należy w tym miejscu przypomnieć, że powyższą analizę wspiera

54 R. Sokolowski Introduction to phenomenology, Cambridge UP, Cambridge 1999, s. 45. 
minimalne założenie co do tego, kim jest graczka: po prostu osobą, która chce grać dalej. Jeśli chcielibyśmy rozszerzyć przypuszczenia o niej, to królestwo interpretacji intersubiektywnych tak samo uległoby rozszerzeniu, być może nawet do tego stopnia, żeby obejmować sądy na temat gustu, które pozostają wszakże idiosynkratyczne w przypadku tego minimalnego założenia.

Wiele interpretacji dotyczących New Vegas w trakcie rozgrywki odnosi się do konkretnej skończoności ujawniającej się w artefakcie New Vegas. Jako maszyna tekstualna New Vegas (poprzez wyłanianie się rozmaitych akcji na wielu różnych ścieżkach) może ujawnić mnóstwo takich „skończoności”. W innym tekście ${ }^{55}$ użyłem Sartre'owskiej idei skończoności ${ }^{56} \mathrm{w}$ analizie GTA: San Andreas (2004), żeby zobrazować różnicę między atemporalnością artefaktu gry a ograniczonością indywidualnej rozgrywki, podczas której każdy dokonany wybór wyklucza inne możliwości. Podobnie tutaj używam koncepcji skończoności, odnosząc się do tego, co można by kolokwialnie nazwać jedną „rozgrywką".

Chociaż mogę być jedyną osobą, która doświadczyła tej konkretnej skończoności gry w New Vegas, zawierającej spotkanie w motelu El Rey ze skorpionami drzewnymi, które wciągnęły mnie w pętlę śmierci, to ten artefakt może ujawnić inne skończoności mnie i innym graczom. Wspólne dla wszystkich takich skończoności jest to, że ujawniły się one wobec dokładnie takiej samej materialności grywalnego artefaktu New Vegas, wyjąwszy różnice w sprzętach komputerowych graczy. Wszystkie skończoności zaczęły się na kanapie Doktora Mitchella, później gracze stanęli przed wyborami, czy pomóc Sunny Smiles pozbyć się irytujących kojotów, czy uwolnić Ringa z więzienia na stacji benzynowej w Goodsprings itd., albo oddalili się, żeby korzystać z własnej wolności do odkrywania wyłaniających się możliwości ponoć „otwartego” świata New Vegas, zanim ostatecznie - jeśli byli wystarczająco cierpliwi lub zaangażowani - zostali wpędzeni w któreś z wielu, także predefiniowanych, zakończeń. Aarseth określał tego typu gry, które pozwalają na różnorodne skończoności rozpięte między predefiniowanym rozpoczęciem i zakończeniem, jako gry z „kremowym środkiem"57. Możliwe, że wydarzenia rozgrywające się po zejściu z kanapy Doktora Mitchella nie mają paralel w świecie empirycznym, podobnie jak wydarzenia w świecie Ferelden z innej gry o „kremowym środku”, Dragon

55 O.T. Leino Emotions in play..., s. 272.

56 J.-P. Sartre Byt inicość, s. 415.

57 E. Aarseth A narrative theory of games, w: Proceedings of FDG '12, May 29-June 1, 2012, s. 132, http://delivery.acm.org/10.1145/2290000/2282365/p129-aarseth.pdf (31.05.2017). 
Age: Origins (2009). Rozróżnienie między tym, co idiosynkratyczne, a tym, co intersubiektywne, jest bezużyteczne w opisie tych potencjalnie niemających paralel wydarzeń: intersubiektywne uprawnienie interpretacji wydarzenia bez paraleli pozostałoby wyłącznie potencjalnością. Co można zatem powiedzieć o modalnościach interpretacji możliwie niemających paraleli wydarzeń w wyłaniającym się „kremowym środku” New Vegas?

Według doktryny ludologicznej gry muszą być „dobrze rozgrywane”, by dało się je zrozumieć. Wziąwszy pod uwagę, że przeżycie wobec oporu jest równoznaczne z sukcesem, oczywiste staje się to, że New Vegas dostarcza więcej niż jednego sposobu „dobrej rozgrywki”. Istnieje mnóstwo skończoności, które mogą rozwinąć się wobec artefaktu New Vegas, mających potencjalne podobieństwa jedynie w rozpoczęciu i zakończeniu. Przytłaczająca liczba hipotetycznych "sposobów dobrej rozgrywki” narusza operacyjność ludologicznej doktryny interpretacji: ze względu na ograniczenia naszego własnego istnienia nie jesteśmy w stanie uzyskać dostępu do wszystkich możliwych skończoności New Vegas.

W ontologicznej analizie gier Aarseth pisał, że „sesja rozgrywki jest rezultatem kombinatorycznie zdeterminowanych wyborów ze strony zarówno gracza, jak i gry"58, oraz postulował istnienie różnicy między "g e n e r a l n ą sesją rozgrywki” a „k o n k r e t n y m i” sesjami rozgrywki, z których pierwsza oznacza coś, do czego nie ma dostępu, zaś druga - coś, z czym gracze stykają się rutynowo. W artykule poświęconym metodologii badania gier Consalvo i Dutton dostrzegli trudności związane z próbą wyczerpującego opisu „wszystkich interakcji” w obrębie gry komputerowej na podstawie własnych obserwacji:

Ekspansywny, zmienny charakter rozgrywki w wiele tytułów może czynić niemożliwym (albo jedynie niewiarygodnym) próby odnotowania albo znalezienia (i analizy) wszystkich dostępnych interakcji, które oferuje się graczowi. ${ }^{59}$

Mimo że obydwa poglądy mówiące o nieosiągalności wyczerpującego opisu są wiarygodne, to należy zauważyć, że poszukiwanie uprawnienia sądu

58 E. Aarseth „Define Real, Moron!".., s. 66.

59 M. Consalvo, N. Dutton Game analysis: developing a methodological toolkit for the qualitative study of games, "Game Studies" 2006 No. 1, http://gamestudies.org/0601/articles/consalvo_ dutton (31.05.2017). 
o niemożliwości takiego opisu nie muszą wychodzić poza poziom rozważań o istnieniu w ogóle: jakikolwiek materialnie istniejący przedmiot, który można postrzec, transcenduje nasze doświadczenie tego przedmiotu; w przypadku grywalnego artefaktu dzieje się tak niezależnie od bogactwa interaktywności albo złożoności jego systemu kombinatorycznego. Jest to jednakże problem wyłącznie w przypadku analizy starającej się uprzedmiotowić swój cel albo przyjmującej, że wyczerpujący opis jest możliwy.

Sokolowski, pisząc o możliwości intersubiektywności, stawia tezę, że da się zrozumieć świat intersubiektywności dzięki skupieniu się na „wspólnym świecie", relacjach indywidualnych podmiotów, które nawiązują ze światem, oraz rzeczach, które posiadają wspólnie. Takie podejście zasadza się na uznaniu transcendencji przedmiotów:

Zdaję sobie sprawę z tego, że kiedy widzę przedmiot z danego kąta, to inni widzą go z jakiegoś innego kąta, kąta, z którego ja bym spoglądał, gdybym znalazł się tam, gdzie oni. [...] Doceniam przedmiot jako transcendujący mój punkt widzenia. ${ }^{60}$

Choć przypuszczalnie nie jestem jedyną osobą, która utknęła w pętli śmierci w New Vegas, to ta konkretna skończoność była wyłącznie moja. Zdaję sobie sprawę, że pętla śmierci jest komponentem innych skończoności, a inni gracze mieli całkowicie inne jej doświadczenie: weźmy pod uwagę np. kogoś, kto zainwestował znaczną ilość czasu i wysiłku w wypełnianie kolejnych questów przed utknięciem w pętli śmierci, ale nigdy nie dokonywał ręcznego zapisu. Można sobie wyobrazić, że utrata tej inwestycji popchnęłaby graczkę do gniewnego ciśnięcia klawiaturą i myszą, któremu akompaniowałoby jakieś brzydkie słowo. Jak najbardziej mógłbym się postawić w jej sytuacji: gdybym podążał tą samą drogą, najprawdopodobniej zirytowałbym się tak samo. Osobiście odebrałem pętlę śmierci jako całkiem interesującą poprzez bycie kolejnym komponentem przypadkowości grywalnego artefaktu, który to komponent da się oznaczyć, a być może jakiś inny odkrywca ${ }^{61}$ albo flâneur $^{62}$ będzie mógł odnieść się do mojego doświadczenia.

60 R. Sokolowski Introduction to phenomenology..., s. 152-153.

R. Bartle Gracze, którzy pasują do MUD-ów, przeł. P. Zająkała, w: Światy z pikseli..., s. 363-408.

62 W. Benjamin O kilku motywach u Badeulaire'a, przeł. S. Surowska, "Przegląd Humanistyczny” $1970 \mathrm{nr} 6$. 
Niezależnie od braku paralel między poszczególnymi sytuacjami związanymi z pętlą śmierci prawdopodobne wydaje się, że inni, którzy znają kondycję rozgrywki New Vegas - którzy, ujmując rzecz kolokwialnie, „już wszędzie byli i wszystko zrobili" - mogą zrozumieć to, co mam na myśli, kiedy mówię o swoim doświadczeniu pętli śmierci.

Choć skończoności rozgrywki w New Vegas stanowią osobiste doświadczenie graczy, to ja i inni gracze rzeczywiście posiadamy „wspólny świat”, kondycję rozgrywki, wobec której rozwijają się skończoności, wkodowaną w materialność grywalnego artefaktu. Być może niektóre cechy tych „wspólnych światów” mogą zostać zakomunikowane między indywidualnymi graczami w ten sam sposób, w jaki możemy jako ludzie zrozumieć pojęcia takie jak „ciepły”, „zimny”, „matka”, „dziecko”. Wydaje się, że sposób, w jaki grywalne artefakty prezentują się jako posiadające znaczenie, może być opisany podobnie, jak sposób, w który wszystkie przedmioty istniejące w świecie jawią się jako mające właściwości dające się zinterpretować jako znaczące.

Ten tryb analizy, który stara się rozumieć możliwe skończoności na podstawie zrozumienia ich wspólnej kondycji, zdaje się wymagać pewnej formy nastawienia, które możemy nazwać „empatią” w imieniu badacza. Należy zauważyć, że empatia nie odnosi się tu do współdzielenia emocji lub odczuwania emocji za kogoś, jak często dzieje się w dyskusjach o emocjach i grach komputerowych ${ }^{63}$, ale do pewnej wrażliwości, receptywności albo nawet „solidarności” ${ }^{44}$ wobec tego, jak inni gracze mogą interpretować ich osobiste skończoności ujawniające się wobec współdzielonej kondycji. Niejasne jest jednakże, jak to nastawienie jest inne od nastawienia, które wciąż przyjmujemy każdego dnia, żeby radzić sobie z innymi ludźmi. Jeśli grywalne artefakty i ich zawiłości będą doświadczane jako znaczące na sposoby podobne, jak inne obiekty istniejące w świecie, to być może wspólne rozumienie grywalnych artefaktów rozwijałoby się w takie sposoby, które są nam znajome jako ludziom. Granice takiego „empatycznego rozumienia”

63 Por. B. Perron A cognitive psychological approach to gameplay emotions, w: Proceedings of DiGRA 2005 Conference: Changing views worlds in play, http://www.digra.org/digital-library/publications/a-cognitive-psychological-approach-to-gameplay-emotions/ (31.05.2017); J. Frome Eight ways videogames generate emotion, w: Situated play, proceedings of DiGRA 2007 Conference, ed. by A. Baba, University of Tokyo, Tokyo 2007.

64 R. Solomon True to our feelings. What our emotions are really telling us, Oxford UP, Oxford 2007, S. 71. 
i możliwości „specjalnej hermeneutyki empatii”"65 $\mathrm{w}$ kontekście interpretacji grywalnych artefaktów to naturalne kierunki dalszej dyskusji, ale zasługują one na jeszcze jeden esej. Zatem po prostu wstępnie zauważę w tym miejscu, że być może empatyczna analiza kondycji materialnych, wobec których ujawniają się skończoności rozgrywki, mogą wypełnić pustkę pozostawioną przez odejście od esencjalistycznych i obiektywizujących strategii w metodologii badania gier.

\section{Wnioski}

Zacząłem od pytania, jak „gry” takie jak New Vegas otwierają się na interpretację i przeszedłem do problematyzowania ludologicznej doktryny interpretacji. To doprowadziło mnie do opisu jednoosobowych gier komputerowych jako grywalnych artefaktów, co z kolei pozwoliło mi zakwestionować założenie o "growości" jednoosobowych gier komputerowych. Zaproponowałem szereg odpowiedzi na początkowe pytanie. Gracze biorą udział w hedonistycznym projekcie interpretacji New Vegas jako gry, dokonując wstecznej inżynierii artefaktu w celu odnalezienia schematu ich egzystencji, który ów artefakt zawiera. Twórcy gier mogą także uprawniać taką interpretację ze względu na to, że ich intencją jest w końcu tworzenie gier. Pisałem, że badacze nie mogą projektować esencji "growości" na artefakt, ponieważ implikowałoby to błąd twórcy i ograniczało multistabilność artefaktu tak, że byłby on postrzegalny tylko do tego stopnia, do którego albo przejawia esencję „growości”, albo mu jej brakuje. Jednakże interpretacja która opiera się na egzystencji bardziej niż na esencji jest możliwa. Ten esej ukazuje możliwość nie tylko idiosynkratycznych, ale także intersubiektywnych interpretacji New Vegas jako istniejącego oraz to, że empatia jest niezbędna, by włączyć cudze świadectwa rozgrywki w świat intersubiektywności.

Porzucenie "growości" jako projektowanej esencji nie narzuca konieczności zignorowania grywalności takiej, jakiej doświadcza się w spotkaniach z grywalnymi artefaktami. To, co zasugerowałem, to jedynie przejście od formułowania założeń na temat przedmiotu badań do pozwolenia na manifestację tego typu grywalności, który jest właściwy grom komputerowym, oraz do prób ujęcia go w takie koncepcje, które niosą ze sobą jak najmniej presupozycji. Zatem w ramach wniosku końcowego należy stwierdzić, że nie jest ani możliwe, ani konieczne zdyskredytowanie użyteczności programu

65 L. Agosta Empathy in the context of philosophy, Palgrave McMillan, London 2009. 
metodologicznego, który implikuje ludologiczna doktryna interpretacji. W analizie empatycznej, omówionej w poprzednim wątku, ostatecznie konieczne jest zajęcie pozycji gracza w centrum wydarzeń. Jeśli „dobra rozgrywka" oznacza ciągłe przeżywanie, jak to już zostało zaproponowane, to dobra rozgrywka pozostaje koniecznością: „przeżycie” kondycji, wobec której ujawniają się skończoności rozgrywki, jest niezbędną podstawą empatycznego rozumienia. W rzeczy samej doktryna ludologiczna do pewnego stopnia nie stwarza problemów jako wytyczna metodologiczna. Niemniej potrzebne są pewne niewielkie korekty: jako poprawkę wypływającą z dyskusji o różnicach między hermeneutycznymi projektami gracza/twórcy i badacza sugerowałbym to, że "granie niezbyt dobrze" jest równie istotne, żeby umożliwić autentyczną i empatyczną analizę oszałamiającego braku formy grywalnego artefaktu jako istniejącego. Kondycji rozgrywki nie można zrozumieć bez eksploracji jej drugiej strony, strony, którą gracz może postrzegać jako przykrą, a twórca jako wadliwą. Innymi słowy, dla autentycznej analizy umieranie i tkwienie w pętlach śmierci jest tak potrzebne jak wygrywanie albo ukończenie gry. 


\section{Abstract}

\section{Olli Tapio Leino}

Death Loop as a Feature

Assuming its premise in the experience of being stuck in a death loop in Fallout: New Vegas (2010), this essay theorises the possibilities of interpretation in single-player computer game play. This amounts to a critical examination of the paradigmatic approach of interpreting computer games as games accessible for analysis and critique through 'research-play'. Comparing the role of rules in the activity facilitated by'playable artefacts' like single-player computer games or pinball machines to rules in traditional, or more accurately "transmedial" (Juul 2003) games, the essay questions the feasibility of considering computer games 'games' and suggests that a defining characteristic of 'playable artefacts' is to be found from the relationship between materiality and process. Situating playable artefacts in the context of post-phenomenological philosophy of technology, the essay differentiates between attitudes of player, designer, and a scholar. The essay argues that analysis of playable artefacts as 'games' is reductive and can be justified only from the perspectives of a player and a game design researcher. Based on analysis of how playable artefacts become meaningful through material resistance, the essay reconfirms the feasibility of the methodological programme of'research-play' while calling for its re-contextualization in relation to authentic interpretation and empathy.

\section{Keywords}

interpretation, Fallout: New Vegas, ludology, bug, feature, materiality, technology, phenomenology 